\title{
Technical Efficiency of Olive-growing Farms in the Northern West Bank of Palestine
}

\author{
Kenichi Kashiwagi ${ }^{1}$ \\ ${ }^{1}$ Faculty of Humanities and Social Sciences, Alliance for Research on North Africa, University of Tsukuba, \\ Tsukuba, Japan \\ Correspondence: Kenichi Kashiwagi, Faculty of Humanities and Social Sciences, Alliance for Research on North \\ Africa, University of Tsukuba. 1-1-1 Tennodai, Tsukuba, Ibaraki 305-8571, Japan. Tel: 81-29-853-3982. E-mail: \\ kashiwagi.kenichi.fn@u.tsukuba.ac.jp
}

$\begin{array}{lc}\text { Received: February 13, } 2017 & \text { Accepted: March 18, } 2017 \quad \text { Online Published: April 11, } 2017 \\ \text { doi:10.5539/sar.v6n2p125 } & \text { URL: https://doi.org/10.5539/sar.v6n2p125 }\end{array}$

\begin{abstract}
This study examines the firm-level technical efficiency of olive-growing farms in the West Bank of Palestine. Using a sample of 176 olive farms in the Jenin governorate collected during September 2015, we estimated the Cobb-Douglas stochastic frontier production function. The results suggest that higher levels of education of the head of farm households and farms with a higher density of olive trees are associated with higher technical efficiency. The introduction of irrigation had a marginal effect on upgrading efficiency. Enlarging the irrigated area had a negative effect, but increasing the number of years of irrigation had a positive impact on efficiency. While the impact of access to export markets on technical efficiency was negative and farms oriented towards domestic consumption of olive oil showed lower efficiency, access to markets through olive presses and middlemen contributed to improve efficiency. The results of the chosen half-normal model suggest that olive farms in Jenin have the potential to increase production by $51.4 \%$ through more efficient use of technology and production inputs. These results imply promotion of intensive farming with mature olive trees and expansion of market access could contribute to improve technical efficiency of olive farms in the West Bank even under severe geographical and geopolitical conditions.
\end{abstract}

Keywords: technical efficiency, olive-growing farms, irrigation, West Bank

\section{Introduction}

One of the solutions, suggested by studies on efficiency, to overcome the low productivity of farms in developing countries is based on realizing the maximum possible output with available resources and given technology. Following the pioneering work of Farrell (1957), myriad theoretical and empirical studies have been devoted to the estimation of stochastic production frontiers and efficiency measures. Studies on efficiency shed light on the stochastic phenomenon and existence of inefficiency, but at the same time they point to the potential for improvement under several constraints. The agriculture sector in the arid and semi-arid Mediterranean regions often operates under constraints such as small size of plots and harsh climatic conditions; thus, improving production efficiency is critical to raising agricultural productivity, even if the contribution of technical change and scale effects is less relevant.

In the Mediterranean region, Palestinian agriculture under Israeli occupation is one such example where there are severe geographical and geopolitical constraints. First, land is segmented owing to the geography of the region and most olive farms are located in mountainous areas. Israeli occupation of Area $\mathrm{C}$ imposes huge constraints on horizontal land expansion. Second, despite the annual rainfall, water is scarce relative to increasing demand, and new development of groundwater is restricted by Israeli authorities. In addition, movement of modern inputs such as fertilizers is restricted. In conjunction with limited water supply, this restricts the scope for vertical expansion of production, i.e., improvements in land productivity. This situation, described by Roy (1999) as de-development, continues to be relevant to Palestinian agriculture even after the Oslo accords. In this context, realizing frontier output under the given constraints is one of the few ways of improving productivity.

Despite the constraints under Israeli occupation, agriculture is a sector of relatively high potential in the Palestinian economy. Within this sector, cultivation of olives and extraction of olive oil have a strategic position and significant relevance to production, job creation and exports. According to the Agricultural Statistics Survey 
2010/2011, the number of olive trees stands at 8.895 million, of which 7.798 million (88\%) were fruit bearing in 2011 (Palestinian Central Bureau of Statistics [PCBS], 2012). The area under olives constitutes $53.9 \%$ of the total cultivated area, or 63.8\% of the total area under horticulture trees in Palestine (PCBS, 2012). It is estimated that production of olives in good harvesting years can produce as much as $15 \%$ to $19 \%$ of agricultural output (World Bank, 2006). The total value of olive oil exports in 2014 was US $\$ 24.7$ million, contributing 66.5\% of total agricultural exports and 2.6\% of total exports (PCBS, 2015a). The contribution of olive production to employment is also sizable. The estimated number of families engaged directly or indirectly in olive production, including the harvesting of olives, is estimated at 100,000 out of a population of 4 million (Ministry of Agriculture, State of Palestine, 2014). Currently, 1,353 people are engaged in olive-oil extraction (PCBS, 2015b).

Regardless of the potential of the Palestinian olive sector, it lags behind compared with Israel and other olive producing countries in the Mediterranean region. Despite the nearly identical natural environment, the average yield of olives in Israel ranges from 1.5 to 2.5 tons per hectare, while it hovers between 0.4 and 2.4 tons in the occupied Palestinian territory (UNCTAD, 2015). The neighboring country of Jordan, which has similar environmental conditions for olive cultivation, enjoys approximately $16.9 \%$ higher productivity than Palestine (Ministry of Agriculture, State of Palestine, 2014). In addition, there is a huge difference in productivity throughout the West Bank, ranging from a high of $167 \mathrm{~kg}$ per dunum to a low of $40 \mathrm{~kg}$ per dunum (UNCTAD, 2015). ${ }^{1}$ According to the Ministry of Agriculture, State of Palestine, productivity remains low relative to its potential and farmers have only basic cultivation skills; this means that productivity levels can be increased by $30 \%$ to $40 \%$ if farmers with small landholdings adopt the appropriate technologies (Ministry of Agriculture, State of Palestine, 2014). Hence, one of the challenges facing the olive sector in Palestine is to realize the maximum possible output, or what is called the frontier output, with available inputs and the current level of technology.

Given these conditions, the objectives of this study are to analyze the technical efficiency of olive farms in the West Bank and to identify the factors that can improve efficiency. We specifically examine the impact of irrigation on technical efficiency. We conducted a survey in September 2015, entitled "Survey of Olive Farms in the West Bank-Jenin," in collaboration with the Palestinian Central Bureau of Statistics (PCBS), to collect micro-data on olive farms in Jenin, located in the West Bank. The sample size was 176, distributed by strata design, and included irrigated farms. We estimated the Cobb-Douglas specification of the stochastic production function using these micro-data to investigate technical efficiency at the farm level, and to investigate the factors determine the level of efficiency.

Several studies have analyzed the technical efficiency of olive-growing farms. ${ }^{2}$ Noteworthy and comparable among them are the studies in Mediterranean countries such as Spain, Greece and Tunisia. Lambarraa, Serra and Gil (2007) assessed relative technical efficiency by decomposing the productivity growth of Spanish olive-growing farms, and found that farm location, age of manager, and composition of the workforce affect efficiency levels. By looking at the heterogeneity of olive farms in Andalusia (Spain), such as the age of olive trees, irrigation, intensity of farming and land slope, Amores and Contreras (2009) examined farm efficiency using data envelopment analysis (DEA). For Greek olive farms, Tzouvelekas, Giannakas, Midmore and Mattas (1999) estimated changes in technical efficiency and total factor productivity from 1987 to 1993 . This study found considerable variations in efficiency levels among farms, but changes in efficiency levels were negligible during the observed period. In addition, and again for olive farms in Greece, Karagiannis and Tzouvelekas (2001) suggested that scale and allocative efficiency played a significant role in explaining output growth during the period 1987-1993. As for the determinants of efficiency, Tzouvelekas, Pantzios and Fotopoulos (2001) found a higher degree of efficiency in organic farming compared with conventional farming in Greece. For olive farms in Turkey, Cukur, Saner, Cukur, Dayan and Adanacioglu (2013) suggested there are huge differences in technical efficiency among olive farms and most olive farms do not operate in their optimal scale. Comparing efficiency between organic and conventional olive farms in Turkey, Artukoglu, Olgun and Adanacioglu (2010) found technical efficiency of conventional olive farms is less than that of organic farms. Ozden and Dios-Palmores (2016), which examined olive oil firms in Tukey from the point of ownership structure, suggested experienced production manager, and extensive specialized training with olive industry have positive effect on efficiency. For Tunisian olive-growing farms, Lachaal, Karray, Dhehibi and Chebil (2005) found that the share of productive trees, the share of skilled labour and agricultural training had a positive impact on improving technical efficiency. Although there are several studies on the estimation of technical efficiency of olive production in Mediterranean countries, few have been done on Palestinian olive growers.

With regard to the effect of irrigation on farming, many studies emphasize the necessity of increasing irrigation 
efficiency in the context of water resource management. Valipour (2015b, 2016b) considered the proportion of area equipped for irrigation to cultivate area is one of the main indices to assess agricultural water management. According to the estimation by Valipour (2013c), the index is significantly lower in Africa compared with Africa. The low value of this index is comparable to the West Bank. While it is expected to increase in Africa, lack of proper water management is considered as a bottleneck resulting in the lower value of this index (Valipour, 2015a). In empirical studies on efficiency of agriculture in Africa, Chebil, Frija and Thabet (2015) examined irrigated wheat farms in Tunisia applying DEA approach, and found source of irrigation, membership in water use association, irrigation management and farm size are determinants. Speelman, D'Haese, Buysse and D'Hase (2008), which investigated smallholder irrigation farmers in South Africa, suggested substantial decreases in water use can be attained with given existing technology and crop choice has a positive and significant effect on efficiency. For horticultural greenhouses in Tunisia, Frija, Chebil, Speelman, Buysse and Van Huylenbroeck (2009) suggested farmer's technical training in greenhouse management, investments in water saving technologies and existence of a fertigation technique on farm have a positive effect on irrigation water use efficiency.

Not only social and economic attributes of farms but also technical aspects of irrigation systems and methods may affect irrigation efficiency. Valipour (2013b) suggested various factors including advantages and disadvantages of surface and pressurized irrigation methods, must be taken into account in the selection of irrigation system. Valipour (2013d) emphasized the importance of being aware of hydrologic parameters including surface water supply. Valipour (2016a) recommended forecasting the most critical rainfall month in semi-arid climate conditions based on meteoroidal information in the previous year. Depending on soil conditions, Valipour (2012b) suggested the significance of selecting a proper drainage system including horizontal and vertical drainage. From the point of difference in irrigation methods, i.e., continuous flow, cutback, fixed surge and variable surge, Valipour (2013a) found cutback and surge irrigation methods were able to increase irrigation efficiency. Based on the empirical study in Iran, Valipour (2012a) implied determination of Hydro-module gives many advantages to experts and farmers, since lack of the poor knowledge about water requirement to agriculture uses results in irrigation inefficiency.

In the case of olive-growing farms, Amores and Contreras (2009) estimated DEA model applied to olive farms in Andalusia. The results of this study suggested efficiency is positively related to the farm size, and efficiency improvements observed in large farms come from adoption of irrigation and newly planted trees. It considered a percentage of the plot irrigated is one of the indicators for typology of olive farms, but the effect of irrigation on efficiency is not explicitly examined. Estimating stochastic frontier production function for Tunisian olive farms, Lachaal et al. (2004) examined the effect of introduction of irrigation on technical efficiency. This study found a positive impact of irrigation; however, effect of irrigation conditions, such as changes of irrigated area, years of irrigation and density of trees, are not considered. As far as we know, our study may be the first study examined the effect of irrigation on technical efficiency in more detailed applying to olive-growing farms in West Bank.

\section{Olive Production and Productivity in Palestine}

Olive production, in general, is characterized by alternating fruit-bearing years, where one year is low bearing and the following is high bearing. Changes in annual precipitation also make production levels and prices more volatile. Table 1 presents the changes in olive production, area and land productivity of irrigated and rain-fed areas in Palestine from 1999/2000 to 2007/2008. Annual production levels and productivity fluctuated owing to the alteration of fruit-bearing years, yet land productivity remained reasonably stable during the observed period. Except for the 2005/2006 season, land productivity of irrigated area was higher than that of rain-fed area. On average, the yield of irrigated areas was $414 \mathrm{~kg}$ per dunum, whereas it was $107 \mathrm{~kg}$ per dunum in rain-fed areas. While irrigated areas showed a slightly increasing trend, the average percentage of irrigated areas remained at $2.5 \%$ of the total bearing area. These results show that the effect of irrigation on production was positive; however, no significant improvement in land productivity was observed. 
Table 1. Change in Olive Production, Area and Land Productivity in Palestine

\begin{tabular}{l|lll|lll}
\hline & Irrigated area & & & Rain-fed area & \\
& $\begin{array}{l}\text { Production } \\
\text { (Metric tonne) }\end{array}$ & $\begin{array}{l}\text { Area } \\
\text { (dunum) }\end{array}$ & $\begin{array}{l}\text { Land productivity } \\
\text { (kg/dunum) }\end{array}$ & $\begin{array}{l}\text { Production } \\
\text { (Metric tonne) }\end{array}$ & $\begin{array}{l}\text { Area } \\
\text { (dunum) }\end{array}$ & $\begin{array}{l}\text { Land productivity } \\
\text { (kg/dunum) }\end{array}$ \\
\hline $1999 / 2000$ & 8,746 & 19,699 & 444 & 147,953 & 880,672 & 168 \\
$2000 / 2001$ & 8,292 & 21,426 & 387 & 30,216 & 863,322 & 35 \\
$2001 / 2002$ & 11,583 & 23,688 & 489 & 132,311 & 864,781 & 153 \\
$2002 / 2003$ & 6,555 & 22,999 & 285 & 78,755 & 865,444 & 91 \\
$2003 / 2004$ & 13,136 & 23,416 & 561 & 128,188 & 872,025 & 147 \\
$2004 / 2005$ & 13,438 & 23,010 & 584 & 71,986 & 877,878 & 82 \\
$2005 / 2006$ & 3,077 & 22,300 & 138 & 134,372 & 866,917 & 155 \\
$2006 / 2007$ & 16,413 & 23,961 & 685 & 34,155 & 875,762 & 39 \\
$2007 / 2008$ & 3,664 & 23,945 & 153 & 82,222 & 893,721 & 92 \\
\hline Average & 9,434 & 22,716 & 414 & 93,351 & 873,391 & 107 \\
\hline
\end{tabular}

Note. Data indicate only bearing area.

Source. Palestinian Central Bureau of Statistics (PCBS). Agricultural Statistics. various editions. Ramallah.

Table 2 presents olive production, area, number of trees and productivity in the West Bank. Land productivity and production per tree differ among regions. Both land productivity and production per tree are higher in the northern West Bank than in the south. While the level of production per tree is almost identical between the northern and the middle of the West Bank, it is less than half in the southern West Bank compared with the northern part. The difference in annual precipitation and soil conditions may explain this difference in land productivity. However, within the northern West Bank, there are substantial regional differences in land productivity. For instance, productivity in the Salfit governorate was more than double that in Qalqiliya in the 2009/2010 season, ranging from $140.9 \mathrm{~kg}$ to $250.1 \mathrm{~kg}$ per dunum (Ministry of Agriculture, State of Palestine, 2014). This high variability may be partially explained by natural factors, such as differences in annual precipitation (UNCTAD, 2015).

Table 2. Olive Production, Area, Number of Trees and Productivity in the West Bank, 2010/2011

\begin{tabular}{l|lllll}
\hline & $\begin{array}{l}\text { Production } \\
\text { (metric tonnes) }\end{array}$ & $\begin{array}{l}\text { Area } \\
\text { (dunum) }\end{array}$ & $\begin{array}{l}\text { Number of } \\
\text { trees }\end{array}$ & $\begin{array}{l}\text { Land productivity } \\
\text { (kg/dunum) }\end{array}$ & $\begin{array}{l}\text { Production per } \\
\text { tree (kg/tree) }\end{array}$ \\
\hline West Bank & 64,474 & 481,568 & $7,436,211$ & 133.9 & 8.7 \\
North of West Bank & 48,889 & 341,578 & $5,134,087$ & 143.1 & 9.5 \\
Middle of West Bank & 10,244 & 73,829 & $1,102,299$ & 138.8 & 9.3 \\
South of West Bank & 5,341 & 66,161 & $1,199,825$ & 80.7 & 4.5 \\
\hline
\end{tabular}

Source. PCBS (2012). Agricultural Statistics Survey 2010/2011. Ramallah.

The Ministry of Agriculture of Palestine formulated a General Framework for the Development of the Olive Sector in Palestine in 2012 in light of the Agricultural Sector Strategy "Shared Vision" of 2011-2014. This framework identifies the ways in which the olive sector can be developed. In the Agriculture Sector Strategy of 2014-2016 "Resilience and Development," olives are identified as one of the main subsectors in agriculture. Currently, with olive cultivation being seen as the backbone of Palestinian agriculture, the Ministry of Agriculture has called for an olive sector strategy. According to UNCTAD (2011), olive oil is a strong candidate amongst Palestine's tradable goods and deserving of promotion. While olive harvests have been highly volatile, they contribute to creating a significant export potential (UNCTAD, 2011). Despite its strategic significance, a significant improvement in land productivity was not observed during the 2000s (Table 1). Compared with Israel and Jordan, the land productivity achieved by most olive farmers remained below the potential (UNCTAD, 2015). According to the Ministry of Agriculture, the major challenge and constraint faced by olive famers in Palestine is low profitability. The weakness in production and productivity of olive farms likely results from the small size of holdings, common ownership and absentee owners, which is related to Israeli occupation, and the parceling of plots because of inheritance. These issues may also explain why only weak technical services are available to farmers and why insufficient opportunities exist for accessing loans that will allow the replacement of ageing trees with high-yielding improved varieties, as well as inadequate pest and disease control (Ministry of Agriculture, State of Palestine, 2014). World Bank (2006) pointed out production costs are up to $30 \%$ higher than in Jordan, despite similar natural conditions. This low and stagnating land productivity implies a low 
contribution of technical change over time. In addition, inefficiencies, i.e., the gap between the potential maximum and current output from available inputs with current technology, may exist.

Although we observed changes in land productivity and compared its regional differences, we must remember that land productivity is only one of the measures of productivity. Improvements in productivity can also arise from technical change, efficiency improvements, scale economies, or some combination of these three factors (Coelli, Rao, O’Donnell, \& Battese, 2005). In Section 3, we will extend our discussion to estimations of the production frontier of olive farms and measurements of their technical efficiency.

\section{Methodology}

\subsection{Model}

We employ the stochastic frontier model to parametrically estimate production frontiers and levels of technical efficiency in olive production. Following Aigner, Lovell and Schmidt (1977), and Meeusen and van den Broeck (1977), the stochastic frontier production function can be expressed as follows:

$$
Y_{i}=F(X ; \beta) \exp ^{v_{i}-u_{i}},
$$

where $Y_{i}$ denotes production output for the $i$ th farm; $\beta$ is a vector of unknown parameters to be estimated; $X$ is a vector of inputs of production and other explanatory variables associated with the $i$ th farm. The disturbance term is composed of two parts. First, $v_{i}$ refers to statistical random disturbance terms, which are assumed to be independently and identically distributed $N\left(0, \sigma_{v}{ }^{2}\right)$. Second, $u_{i}$ is the one-sided non-negative random disturbance term, and its distribution is assumed to be independently and identically distributed but is modelled using different distributional assumptions. Aigner et al. (1977) assumed a half-normal distribution at zero mean, i.e., $u_{i} \sim$ iid $N^{+}\left(0, \sigma_{u}{ }^{2}\right)$. Stevenson (1980) introduced the truncated normal formulation, i.e., $u_{i} \sim$ iid $N^{+}(\mu, \sigma$ ${ }_{u}^{2}$ ). Meeusen and van den Broeck (1977) assigned an exponential distribution, whereas Greene (1990) introduced a gamma distribution. Jondrow, Lovell, Materov and Schmidt (1982) considered both a half-normal and an exponential distribution. Reifschneider and Stevenson (1991) modelled gamma, truncated normal and exponential distributions.

Based on the above, the technical efficiency of production of the $i$ th farm can be defined as:

$$
T E_{i}=\frac{F\left(X_{i} ; \beta\right) \exp \left(v_{i}-u_{i}\right)}{F\left(X_{i} ; \beta\right) \exp \left(v_{i}\right)}=\exp \left(-u_{i}\right) .
$$

Following Kumbhakar, Ghosh and McGuckin (1991), Huang and Liu (1994), and Battes and Coelli (1995), we adopt a single-stage approach for the estimation of stochastic production and inefficiency equation. In this approach, explanatory variables are inserted directly into the inefficiency error component. Either the mean or the variance of the inefficiency error components is assumed to be a function of explanatory variables. The technical inefficiency effect, $u_{i}$, in the stochastic frontier model is specified in Equation (3):

$$
u_{i}=\delta^{\prime} z_{i}+w_{i},
$$

where $\delta$ is a vector of the unknown parameters to be estimated; $z_{i}$ is a vector of explanatory variables associated with technical inefficiency in production; $w_{i}$ is a random variable.

For estimating the stochastic frontier model, we specify the production function as taking the Cobb-Douglas form:

$$
\ln Y_{i}=\beta_{0}+\sum_{j=K, L, A}^{A} \beta_{j} \ln X_{j i}+v_{i}-u_{i},
$$

where $Y_{i}$ represents the quantity of olive production measured in $\mathrm{kg} ; j$ represents inputs used in olive production $(j=K, L, A) ; \beta_{0}$ and $\beta_{\mathrm{j}}$ are the unknown parameters to be estimated; $X_{K i}$ is the capital stock used for olive production measured in new Israeli shekel (NIS); $X_{L i}$ is total labour used to olive production; $X_{A i}$ is the total land area devoted to olive production measured in dunum; $v_{i}$ is the symmetric disturbance term accounting for random shocks and other statistical noise; $u_{i}$ is the one-sided non-negative random disturbance term denoting technical inefficiency. The dummy variable for the introduction of irrigation, $D_{I R i}$, is included to control for farm 
characteristics in the estimation.

The model of technical inefficiency effect could be specified as follows:

$$
u_{i}=\delta_{0}+\sum_{h=1}^{H} \delta_{h} z_{h i}+w_{i}
$$

where $z_{h}(h=1,2, \ldots, H)$ is the farm-specific efficiency related variables. Regarding the factors affecting efficiency, many studies consider human capital as one of the determinants of agricultural production (Kaliranjan \& Shand, 1985; Stefanou \& Saxena, 1988; Gorton \& Davidova, 2004). For olive production in Tunisia, a positive effect of human capital on efficiency was confirmed by Lachaal et al. (2004) and Lachaal et al. (2005), which represented human capital as a share of skilled labour.

On the other hand, several studies have examined the impact of intensification, represented by density of olive trees, on the level of efficiency. According to Beaufoy (2001), olive farms in European countries are generally categorized into three types: low-input traditional farms, intensive traditional farms and intensive modern farms. In these categories, the range of olive tree density is one of the major indicators for typology. Yields varied significantly from $200 \mathrm{~kg}$ to $10,000 \mathrm{~kg}$ per ha, based on the type of farm. Comparing the levels of olive farming intensity in Spain, Italy, Greece and Portugal, Weissteiner, Strobl and Sommer (2011) found strong intensification in Spain, followed by Italy, Greece and Portugal. While these studies focused on heterogeneity, the typology of olive farms and differences in land productivity, they lacked discussions on how they affected efficiency.

Introduction of irrigation is a critical factor in the intensification of olive farming. Drip irrigation technology has now become major practice in new farms. Traditional type of olive farming is being intensified by the introduction of drip irrigation, and densified by planting new trees in the rows between existing trees (Beaufoy, 2001). As for the effect of irrigation on efficiency, a positive impact was found by Lachaal et al. (2004) for Tunisian olive growers. In addition to the intensity of land and irrigation operation, Amores and Contreras (2009) found that the age of olive trees is one of the major factors explaining the heterogeneity of olive farms in Andalusia. In our model, we test the impact of increasing the number of years under irrigation on technical efficiency. Many studies suggested a negative correlation between farm size and efficiency in agricultural operations (Bravo-Ureta \& Evenson, 1994; Ali, Parikh, \& Shah, 1994; Hallam \& Machado, 1996; Bozoğlu \& Ceyhan, 2007). Our model examines the effect of expansion of irrigated land on efficiency.

Regarding market access, Hart, Miljkovic and Shafik (2015), Miljkovic and Shaik (2010), and Miljkovic, Miranda and Shaik (2013) examined the effect of trade openness on technical efficiency. However, most studies found no or even a negative impact on efficiency. In this model, we test the variables of access to export markets, middlemen and olive presses to examine their impact on technical efficiency.

The technical inefficiency effect of the $i$ th farm is defined by equation (6):

$$
\begin{aligned}
u_{i}= & \delta_{0}+\delta_{1} E D U_{i}+\delta_{2} T R D_{i}+\delta_{3} R I R_{i}+\delta_{4} Y I R_{i}+\delta_{5} D M_{M D i} \\
& +\delta_{6} D M_{E X i}+\delta_{7} D M_{O P i}+\delta_{8} D D_{H H i}+w_{i}
\end{aligned}
$$

where $E D U$ denotes level of education of the head of the farm household; TRD denotes the density of olive trees; $R I R$ represents the proportion of irrigated area to the total area; $Y I R$ is years under irrigation. We include dummy variables to represent the access to markets for extracted olive oil; thus, $D M_{M D}$ stands for farms that sell olive oil to middlemen (merchants); $D M_{E X}$ represents farms that sell olive oil to consumers abroad (export); $D M_{O P}$ represents farms that sell olive oil to olive presses. The dummy variable $D D_{H H}$ denotes farms that consume olive oil domestically. $\delta_{i}(i=0 \ldots 8)$ is an unknown parameter to be estimated, and $w_{i}$ represents the error term. All parameters of the stochastic frontier production function in Equation (4) and the model for technical inefficiency effects in Equation (6) are estimated using single-stage maximum likelihood estimation (MLE) (Reifschneider \& Stevenson, 1991; Huang \& Liu, 1994).

\subsection{Data}

The data used in this study is drawn from the "Survey on Olive Farms in West Bank-Jenin" conducted in collaboration with the PCBS during September 2015. The area of land cultivated with horticultural crops including olives was 659,894 dunums in the Palestinian Territory, including 612,649 dunums in the West Bank and 47,245 dunums in Gaza Strip. In the West Bank, the largest cultivated area for horticulture trees was in the 
Jenin governorate (17.9\%) in 2010/2011 (PCBS, 2012). The survey chose this governorate because of the large area under olive cultivation. The area under olive-bearing trees in Jenin was 92,028 dunums and 96,335 tons of olives were produced in 2009/2010, the highest in Palestine (Ministry of Agriculture, State of Palestine, 2014). However, the average productivity of Jenin is lower than any other governorate in the northern West Bank. These figures point to the potential for the expansion of olive production in Jenin.

The sample size of the analysis was 179 olive holdings distributed by strata design. A one-stage stratified random sampling methodology was used and response rate was $89.5 \%$. The 179 farm data included irrigated and non-irrigated farms. Owing to missing information on the level of education and years under irrigation, three data points were dropped. This left data for 176 olive farms which could be subjected to empirical analysis. Table 3 presents the summary statistics of the variables. The dependent variable of the production function $Y$ is the production of olives measured in $\mathrm{kg}$. The stock of physical capital $(K)$ is the total present value of all machinery and equipment used for olive production. Labor input, $L$, is represented by the total number of labor used in production, including family and employed labor. Land, $R$, represents total cultivated area measured in dunum. A dummy variable of $D_{I R}$ captures the impact of irrigation. With regard to the independent variables of the inefficiency effects model, $E D U$ represents a discrete variable of the farm head's level of education, ranging from illiterate to doctorate holder. As a variable of intensive production, we include a variable of the density of olive trees, TRD, measured by number of olive trees per dunum. A variable of the proportion of irrigated area to the total area, RIR, is added to examine the effect of expansion of irrigated area, and YIR denotes years under irrigation. To examine the effect of marketing, we include a dummy variable, $D M_{M D}$, representing farms that sell olive oil to middlemen (merchants). Access to export markets, a dummy variable of $D M_{E X}$ is included representing farms that sell olive oil to consumers abroad. A dummy variable $D M_{O P}$ represents farms that sell olive oil to olive presses. As some farms use the extracted olive oil by themselves, a dummy variable $D D_{H H}$ is added denoting farms that consume domestically.

Table 3. Summary Statistics of the Variables

\begin{tabular}{|c|c|c|c|c|}
\hline Variables and measurement & Mean value & $\begin{array}{l}\text { Standard } \\
\text { deviation }\end{array}$ & Maximum & Minimum \\
\hline$Y$ : Production of olives $(\mathrm{kg})$ & 3503.9 & 5725.5 & 42167 & 33 \\
\hline$K$ : Value of capital stock in use (NIS) & 470.6 & 1249.4 & 0.0 & 7782.6 \\
\hline$L:$ Number of labour & 7.9 & 5.7 & 1 & 36 \\
\hline$R:$ Cultivated area (dunum) & 21.5 & 26.5 & 1 & 188 \\
\hline $\begin{array}{l}D_{I R}: \text { Dummy variable of irrigation (1: introduce } \\
\text { irrigation, } 0: \text { otherwise) }\end{array}$ & 0.216 & 0.413 & 1 & 0 \\
\hline $\begin{array}{l}E D U: \text { Level of education (1: illiterate, 2: can read } \\
\text { and write, 3: elementary, 4: preparatory, 5: } \\
\text { secondary, 6: associate diploma, 7: bachelor, 8: } \\
\text { higher diploma, 9: master, 10: Ph.D.) }\end{array}$ & 4.6 & 2.0 & 1 & 10 \\
\hline TRD: Density of olive trees (number/dunum) & 15.5 & 3.1 & 8.0 & 24.0 \\
\hline$R I R$ : Proportion of irrigated area to total area & 0.072 & 0.169 & 1.0 & 0.0 \\
\hline YIR: Years under irrigation (years) & 0.857 & 2.025 & 15 & 0 \\
\hline $\begin{array}{l}D M_{M D} \text { : Dummy variable of market of middlemen (1: } \\
\text { sell olive oil to middlemen, } 0 \text { : otherwise) }\end{array}$ & 0.102 & 0.304 & 1 & 0 \\
\hline $\begin{array}{l}D M_{E X}: \text { Dummy variable of market of export (1: sell } \\
\text { olive oil to consumers in abroad, } 0 \text { : otherwise) }\end{array}$ & 0.011 & 0.106 & 1 & 0 \\
\hline $\begin{array}{l}D M_{O P} \text { : Dummy variable of market of olive presses } \\
\text { (1: sell olive oil to olive presses, } 0 \text { : otherwise) }\end{array}$ & 0.102 & 0.304 & 1 & 0 \\
\hline $\begin{array}{l}D D_{H н} \text { : Dummy variable of domestic consumption (1: } \\
\text { use olive oil in house, } 0 \text { : otherwise) }\end{array}$ & 0.364 & 0.482 & 1 & 0 \\
\hline
\end{tabular}

\section{Empirical Results and Discussion}

Table 4 presents coefficient estimates and corresponding standard errors. Maximum likelihood estimators based on the Cobb-Douglas stochastic frontier model and the technical inefficiency effects model are estimated using the STATA11 package. We estimate three models following the distributional assumptions of half-normal, truncated normal and exponential for the one-sided error term $\left(u_{i}\right)$. As the hypothesis of constant returns to scale 
(CRTS) cannot be rejected at the $10 \%$ level, we estimate three models with different distributional assumptions imposing a restriction of the CRTS. The likelihood-ratio (LR) test rejects the null hypothesis that the inefficiency effects are absent, i.e., $\sigma_{u}=0$, in the half-normal and exponential models. In the truncated normal model, the estimates of the variance parameters $\sigma$ and $\gamma$ are positive and statistically significant at the $1 \%$ level. In addition, the LR test rejected the null hypothesis of no farm-specific effects (i.e., $\delta_{1}=\delta_{2}=\delta_{3}=\delta_{4}=\delta_{5}=\delta_{6}=\delta_{7}=\delta_{8}=0$ ) at the 5\% level of significance. These results suggest that inefficiency effects are significant for explaining differences in olive production.

The half-normal distribution model is nested in the truncated normal distribution for the one-sided error term. However, the LR test cannot reject the null hypothesis that the truncated normal distribution for $u_{i}$ is inappropriate. Hence, the use of the half-normal distribution for $u_{i}$ could not be rejected. Regarding the selection of half-normal and exponential distributions, the Akaike and Bayesian information criteria (AIC and BIC) were applied as the two models are non-nested. Both criteria favor the half-normal distribution; this distribution minimizes values of AIC and BIC relative to the exponential distribution. This implies that the half-normal distributional assumption is more appropriate than that of the exponential distribution.

Table 4. Coefficients and Standard Errors of the Stochastic Frontier and Inefficiency Effects Models

\begin{tabular}{|c|c|c|c|c|c|c|c|c|c|}
\hline \multirow[b]{2}{*}{ Variable } & \multicolumn{3}{|c|}{ Normal-Half normal } & \multicolumn{3}{|c|}{ Normal-Truncated normal } & \multicolumn{3}{|c|}{ Normal-Exponential } \\
\hline & \multicolumn{2}{|c|}{ Coefficient } & \multirow[t]{2}{*}{$\begin{array}{c}\text { standard } \\
\text { error }\end{array}$} & \multicolumn{2}{|c|}{ Coefficient } & \multirow[t]{2}{*}{$\begin{array}{l}\text { standard } \\
\text { error }\end{array}$} & \multicolumn{2}{|c|}{ Coefficient } & \multirow[t]{2}{*}{$\begin{array}{c}\text { standard } \\
\text { error }\end{array}$} \\
\hline Stochastic frontier model & & & & & & & & & \\
\hline Constant & 5.903 & $* * *$ & 0.062 & 5.977 & $* * *$ & 0.074 & 5.733 & $* * *$ & 0.109 \\
\hline $\operatorname{Ln} K$ & 0.045 & . & 0.024 & 0.044 & * & 0.025 & 0.045 & * & 0.027 \\
\hline $\operatorname{Ln} L$ & 0.120 & $* * *$ & 0.041 & 0.131 & $* * *$ & 0.042 & 0.136 & $* *$ & 0.060 \\
\hline Implicit parameter of $\operatorname{Ln} A$ & 0.835 & & & 0.824 & & & 0.819 & & \\
\hline$D_{I R}$ & -0.144 & & 0.101 & -0.173 & & 0.114 & -0.130 & & 0.115 \\
\hline Inefficiency effects model & & & & & & & & & \\
\hline Constant & 2.438 & $* * *$ & 0.706 & 2.439 & $* * *$ & 0.659 & 2.243 & ** & 1.039 \\
\hline$E D U$ & -0.128 & $* *$ & 0.063 & -0.119 & * & 0.065 & -0.173 & 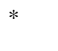 & 0.095 \\
\hline$T R D$ & -0.109 & $* * *$ & 0.036 & -0.093 & ** & 0.041 & -0.139 & ** & 0.055 \\
\hline$R I R$ & 3.347 & **** & 1.268 & 1.605 & & 1.208 & 4.122 & *** & 1.886 \\
\hline YIR & -0.333 & *** & 0.063 & -0.260 & * & 0.144 & -0.411 & *** & 0.187 \\
\hline$D M_{M D}$ & -0.986 & *** & 0.410 & -0.827 & & 0.524 & -1.252 & * & 0.648 \\
\hline$D M_{E X}$ & 2.577 & ** & 1.049 & 2.973 & $* * *$ & 0.847 & 3.442 & ** & 1.519 \\
\hline$D M_{O P}$ & -1.622 & $* * *$ & 0.458 & -1.638 & ** & 0.695 & -2.263 & & 0.809 \\
\hline$D D_{H H}$ & 0.609 & ** & 0.706 & 0.594 & ** & 0.258 & 0.732 & $*$ & 0.390 \\
\hline Variance parameters & & & & & & & & & \\
\hline $\ln \sigma_{v}^{2}$ & -3.382 & $* * *$ & 0.502 & & & & -2.538 & *** & 0.639 \\
\hline$\sigma^{2}$ & & & & 0.950 & $* * *$ & 0.255 & & & \\
\hline$\gamma$ & & & & 0.973 & $* * *$ & 0.015 & & & \\
\hline Log-1 & -163.264 & & & -162.682 & & & -170.686 & & \\
\hline No. of observations & 176 & & & 176 & & & 176 & & \\
\hline AIC & 354.527 & & & 355.364 & & & 369.373 & & \\
\hline BIC & 398.914 & & & 402.921 & & & 413.760 & & \\
\hline
\end{tabular}

Note. ${ }^{*}, * *, * * *$ indicate significance at the $10 \%, 5 \%$ and $1 \%$ levels, respectively.

The statistical problem to be resolved in this model is the possibility of endogeneity of TRD and RIR. These variables might be correlated with the error term. If endogeneity exists, the estimations may produce biased and inconsistent results. Following Wooldridge (2002), and Davidson and MacKinnon (2004), we employ the instrumental variable method. Applying the Durbin-Wu-Hausman test for endogeneity, we specify equations showing that the decision regarding the degree of tree density $(T R D)$ and that for choosing the proportion of area of irrigation $(R I R)$ are affected by four instrumental variables: cost of water $\left(C_{W}\right)$, distance to olive presses $(D T P)$, a dummy variable for intention to own olive-oil milling $\left(D_{I O}\right)$ and another dummy for intention of direct milling $\left(D_{I D}\right)$. These instrumental variables are selected since they are highly correlated with the variables $T R D$ and $R I R$ but not with the error term of equation (6). To test for endogeneity, we first estimate the equation that includes the independent variables of equation (6) plus a set of the instrumental variables. Then, we estimate the original 
equation (4), including the residuals obtained from the first estimation. Under the null hypothesis of the existence of endogeneity, the coefficients of these additional residual terms do not equal zero. If the null hypothesis is rejected, TRD and RIR are not endogenous. Following this method, the endogeneity test shows that the coefficients of the residual terms are insignificant, even at the $10 \%$ level. This result thus rejects the possibility of endogeneity of TRD and RIR.

The results of the preferred half-normal model suggest that the signs of the estimated parameters are as expected. The estimated coefficients of capital stock and labor input are positive and statistically significant, confirming that these are significant factors in determining the level of output. Surprisingly, the irrigation dummy is not statistically significant. This implies that irrigation does not contribute significantly to increasing the output level.

The estimated results of the chosen half-normal model and the other two models are largely consistent vis-à-vis the determinants of efficiency, except for the proportion of irrigated area $(R I R)$ and the market of middlemen $\left(D M_{M D}\right)$ variables, which are not significant in the truncated normal model. From the estimated coefficients of the inefficiency equation, three major factors are found to positively affect the level of efficiency. First, the estimated coefficient of education level $(E D U)$ is negative and statistically significant. This result shows that human capital accumulation contributes to improving efficiency. The positive impact of human capital such as education, agricultural experience and training on efficiency in agricultural production has been widely confirmed (Kaliranjan \& Shand, 1985; Stefanou \& Saxena, 1988; Gorton \& Davidova, 2004; Solís, Bravo-Ureta, $\&$ Quiroga, 2009). For olive farms in Tunisia, Lachaal et al. $(2004,2005)$ found a positive relationship between the share of skilled labor and technical efficiency. To estimate equation (6), we test the significance of the variables of age of farm head as well as years of farming and training, but only the education level of the farm head was found to be significant.

Second, the estimated coefficient of the density of olive trees (TRD) is negative and significant. This suggests that more intensive cropping is associated with higher efficiency. According to the typology of Beaufoy (2001), for olive growers in Europe, tree density ranges from 80 to 250 trees per ha in intensive traditional farms, whereas it ranges from 200 to 400 trees per ha in intensive modern farms. In Jenin, the average number of olive trees is 166 per ha, ranging from 88 to 266 trees. For olive farming in Andalusia, Amores and Contreras (2009) established that modern techniques such as irrigation as well as new plantations and intensive farming are the most important factors in current technical efficiency. ${ }^{3}$ Following the typology of Beaufoy (2001), olive farms in Jenin can be categorized as intensive traditional farms; and the evidence provided by Amores and Contreras (2009) suggests the possibility of improving efficiency in Jenin through intensification of cropping.

In addition, years under irrigation $(Y I R)$ yielded a negative, significant coefficient. This suggests that farms become more efficient as the number of years of irrigation increases. Regarding the relationship between irrigation and technical efficiency, Frija et al. (2009) revealed a positive association between irrigated water use efficiency and technical efficiency for horticultural greenhouse farms in Tunisia. Proietti and Antognozzi (1996) examined the relationship between irrigation, productive activity and fruit quality of table olives (cultivar "ascolana tenera"), and concluded that irrigation contributed to improve the commercial value of the fruit by increasing the size and pulp/pit ratio and intensifying fruit coloring. The results herein are consistent with these previous studies. Amores and Contreras (2009), who classified olive farms in Andalusia, considered the unproductive youth period of olive trees to be 10 years; and the average number of years under irrigation in their sample is eight. According to Lachaal et al. (2004), increasing the share of productive olive trees, i.e., those that are between 20 and 70 years old, has a positive effect on improving efficiency in Tunisia. These results imply that more mature irrigated olive trees produce more fruit even if other inputs are held constant.

On the contrary, the estimated coefficient of the proportion of irrigated area $(R I R)$ is positive and statistically significant. This result is unsurprising but consistent with the negative relationship between farm size area and efficiency. Further, this accords with prior studies that have found a negative relationship between farm size and level of technical efficiency in agricultural production (Bravo-Ureta \& Evenson, 1994; Ali et al. 1994; Hallam \& Machado, 1996; Bozoğlu \& Ceyhan, 2007). For Greek olive farms, Tzouvelekas et al. (2001) suggested that larger farms tend to have lower efficiency than small farms. These results imply that enlarging the irrigated area does not contribute to efficiency increases in Jenin, whereas more intensive cropping with mature olive trees is a positive factor in improving efficiency.

Fifth, the estimated coefficients of the dummy variables $D M_{M D}$ and $D M_{O P}$ are negative and statistically significant. These results suggest that farms that sell their extracted olive oil to middlemen and olive presses exhibit higher efficiency. Moreover, the estimated coefficient of $D D_{H H}$ is positive and significant. This suggests 
that efficiency is lower on farms that consume olive oil domestically. Regarding the effect of access to export markets $\left(D M_{E X}\right)$, the estimated coefficient is positive and statistically significant. Thus the effect of access to export markets on efficiency is negative, which does not immediately appear to accord expectation. However, Hart et al. (2015) examined the impact of trade openness on technical efficiency of the EU's agricultural sector. This study suggested trade openness has an immediate negative impact on efficiency, but it contributes to increase efficiency over time. For US agriculture, over 1948-2006, Miljkovic and Shaik (2010) found that a decrease in the share of agricultural imports to agricultural GDP had a positive impact on increasing technical efficiency, whereas an increase in the share of agricultural exports had no impact. In Brazilian agriculture, Miljkovic et al. (2013) found increased exports do not have a significant impact on technical efficiency. In the case of Palestine, the main destination of olive oil exports has long been Israel, with the exports averaging 4,000 tons per year (UNCTAD, 2015). However, the customs union arrangement imposed by Israel on the occupied territories prevented the entry of Palestinian products into Israel while Israel's own heavily subsidized products are allowed to enter freely into Palestinian markets (Naquib, 2003). Palestinian farmers have reduced the use of fertilizers considerably following Israeli restrictions on imported agricultural inputs (UNCTAD, 2015). In addition, the large migration of Palestinian workers to Israel and the transmission of inflationary trends in the Israeli economy to Palestinian markets have eroded the competitiveness of Palestinian trade (Astrup \& Dessus, 2001; Abugamea, 2010). These asymmetric trade relations between Palestine and Israel may prevent expanding Palestinian opportunities for olive oil exports. In this sample, indeed, access to export markets is quite limited. Although most studies have been unable to confirm the positive link between trade openness and technical efficiency, we found a negative impact of efficiency in the case of Jenin. In other words, access to local markets seems to be more relevant than access to export markets. The negative sign of $D M_{M D}$ and $D M_{O P}$ as well as the positive sign of $D D_{H H}$ imply market-oriented farms are associated with higher efficiency. Saldias and von Cramon-Taubadel (2012) found that market access, measured by distance to the nearest main road, has a positive effect on farm efficiency for small farmers in Chile. Although the impact of openness to export markets on efficiency is negative, market-oriented farms seem to be relatively efficient.

The frequency distribution of technical efficiency is presented in Table 5. The average level of technical efficiency of the half-normal and truncated normal models are $48.6 \%$ and $46.1 \%$, respectively, whereas it is estimated at $55.9 \%$ for the exponential model. The estimated efficiency scores of the preferred half-normal model indicate the existence of technical inefficiency in olive farms. The average level of technical efficiency is estimated at $48.6 \%$, ranging from a minimum of $2.0 \%$ to a maximum of $95.3 \%$. It is suggested that farms in this sample are producing, on average, at $51.4 \%$ of their potential at the current levels of technology and input. Sixty-nine farms (39.2\% of the total sample) are relatively inefficient on a within-sample basis, with scores of less than $40.0 \%$. It should be noted that the level of technical efficiency of $22.7 \%$ of sample farms ranges from $20.0 \%$ to $40.0 \%$ while there exists $23.9 \%$ of farms whose efficiency is between $60.0 \%$ and $80.0 \%$. As there are two distinct peaks, i.e., two local maxima in a histogram around $20.0 \%$ and $80.0 \%$ of efficiency level with a valley separating them, the pattern of the distribution of efficiency can be bimodal. This pattern implied there are both less efficient group and more efficient group of farms. Comparing this bimodal pattern of efficiency distribution between irrigated and non-irrigated farms, the pattern is rather multimodal for non-irrigated farms, and for irrigated farms we found two local maxima around $40.0 \%$ and $70.0 \%$ of efficiency level. It implied level of efficiency seems to be converging for irrigated farms compared with non-irrigated. 
Table 5. Frequency Distribution of Technical Efficiency

\begin{tabular}{l|lll}
\hline & $\begin{array}{l}\text { Normal- } \\
\text { Half normal }\end{array}$ & $\begin{array}{l}\text { Normal- } \\
\text { Truncated normal }\end{array}$ & $\begin{array}{l}\text { Normal- } \\
\text { Exponential }\end{array}$ \\
\hline Efficiency levels & & 33 & \\
$\mathrm{TE}<0.2$ & 29 & 33 & 19 \\
& $(16.5)$ & $(18.8)$ & $(10.8)$ \\
$0.2<\mathrm{TE}<0.4$ & 40 & 48 & 38 \\
& $(22.7)$ & $(27.3)$ & $(21.6)$ \\
$0.4<\mathrm{TE}<0.6$ & 39 & 35 & 30 \\
& $(22.2)$ & $(19.9)$ & $(17.0)$ \\
$0.6<\mathrm{TE}<0.8$ & 42 & 36 & 49 \\
& $(23.9)$ & $(20.5)$ & $(27.8)$ \\
$\mathrm{TE}>0.8$ & 26 & 24 & 40 \\
& $(14.8)$ & $(13.6)$ & $(22.7)$ \\
\hline Efficiency scores & & & \\
Mean & 0.486 & 0.461 & 0.559 \\
Median & 0.477 & 0.438 & 0.610 \\
Standard deviation & 0.259 & 0.255 & 0.261 \\
Minimum & 0.020 & 0.019 & 0.024 \\
Maximum & 0.953 & 0.934 & 0.980 \\
\hline
\end{tabular}

Note. Percentages are in parentheses.

These wide variations in the level of technical efficiency in olive production are not surprising; however, the average level of technical efficiency is discernably low in the case of the West Bank. For comparison with other olive producing countries in the Mediterranean region, the overall technical efficiency of olive farms in Greece was stable from $74.9 \%$ (1987) to 76.8\% (1993) (Tzouvelekas et al., 1999), whereas it showed a decreasing trend in the case of the island of Crete, from $87.5 \%$ to $63.7 \%$ during the same period (Tzouvelekas, Giannakas, Midmore, \& Mattas, 1997). Similarly, the estimated level of technical efficiency for Spanish olive farms was $75.5 \%$ on average during the period 1999-2002 (Lambarraa et al., 2007). For Tunisian olive farms, the estimated technical efficiency for the Mahdia region was $83.5 \%$ on the basis of data collected from 1999 to 2002 (Lachaal et al., 2004), whereas it was $82 \%$ for farmers in the Sfax region, over the period from 1994 to 1997 (Lachaal et al., 2005). The estimated results of technical efficiency for farmers in Jenin reveal the existence of relatively inefficient farms; however, they also suggest the possibility of increasing production by $51.4 \%$, given the current state of technology and input levels.

Results of the comparison of efficiency scores between irrigated and non-irrigated farms are presented in Table 6 . In all distributional assumptions, average technical efficiency of irrigated olive farms is slightly higher than that of non-irrigated farms; however, the difference is not statistically significant. In the agricultural sector in Mediterranean countries, Hassine (2007) found a positive impact of the introduction of irrigation on technical efficiency. In wheat production in Tunisia, the increase in water resources and adherence to a water users' association were associated with higher efficiency (Chebil et al., 2015). For olive farmers in the Mahdia region of Tunisia, Lachaal et al. (2004) found a positive impact of irrigation on efficiency improvement.

Despite these findings in some regions of Mediterranean countries, in the West Bank of Jenin, the introduction of irrigation does not significantly contribute to increase efficiency. One possible explanation is the difference in age of olive trees between irrigated and non-irrigated. Amores and Contreras (2009) considered the youth the age of olive trees below 10 years old is unproductive youth period. For the analysis on Tunisia olive farms, Lachaal et al. (2004) used the share of productive olive trees from 20 to 70 years old as an explanatory variable of the inefficiency equation. The finding suggests a positive impact of increasing in the share of productive trees on efficiency improve. These results suggest increasing number of productive trees may contribute to increase efficiency. However, in the case of Jenin, the average age of irrigated olive trees, non-irrigated are 41, 44, respectively. As the difference in the average age of trees is marginal, the explanation by the difference in age of trees is less relevant. Another possible explanation is the effect of scale inefficiency. Results of efficiency analysis on olive farms using DEA by Amore and Contreras (2009) in Andalusia suggested that overall efficiency score under the assumption of variable returns to scale is higher in irrigated farms than non-irrigated, but the score of scale efficiency of irrigated farms is lower than that of non-irrigated. These results suggest 
irrigated olive farms are technically efficient but inefficient in scale compared with non-irrigated. This experience in Spain implies the difficulty to realize optimal scale even for more advanced olive farms in Andalusia. Going back to the case of Jenin, our estimation of technical efficiency scores in Table 6 includes scale efficiency or inefficiency. The relatively low scores of technical efficiency in irrigated farms may reflect scale inefficiency. However, for more detailed analysis, we need to implement DEA to estimate pure technical efficiency differentiated from scale efficiency.

Table 6. Comparison of Technical Efficiency between Irrigated and Non-Irrigated Farms

\begin{tabular}{l|llll}
\hline & $\begin{array}{l}\text { Normal- } \\
\text { Half normal }\end{array}$ & $\begin{array}{l}\text { Normal- } \\
\text { Truncated normal }\end{array}$ & $\begin{array}{l}\text { Normal- } \\
\text { Exponential }\end{array}$ & $\begin{array}{l}\text { Number of } \\
\text { observations }\end{array}$ \\
\hline Technical efficiency & 0.503 & 0.488 & 0.576 & 38 \\
of irrigated farms & $(0.248)$ & $(0.247)$ & $(0.245)$ & \\
\hline Technical efficiency & 0.481 & 0.454 & 0.555 & 138 \\
of non-irrigated farms & $(0.263)$ & $(0.258)$ & $(0.265)$ & \\
\hline Mean difference & 0.022 & 0.034 & 0.021 & \\
$t$-statistics & 0.462 & 0.726 & 0.439 & \\
\hline
\end{tabular}

Note. Standard deviations are in parentheses.

\section{Conclusion}

To our knowledge, this study may be the first attempt to examine the technical efficiency of olive farms in Palestine. The objective is to estimate the level of technical efficiency and identify the sources of efficiency in olive production. Collaborating with the PCBS, we implemented the survey on olive-growing farms in Jenin during September 2015. Using the collected data of 176 olive farms, we estimated a Cobb-Douglas stochastic frontier production function simultaneously with technical inefficiency effects.

Our empirical results suggest that the education level of the head of farm households and a higher density of olive trees contribute to improve the technical efficiency of olive farms in Jenin. Increasing the years of irrigation has a positive impact on efficiency but enlarging the irrigated area has a negative effect. Access to export markets is actually limited, but farms exporting olives are associated with lower efficiency. While those farms which use olives domestically exhibited lower efficiency, farms with access to middlemen and olive oil presses, i.e., market-oriented farms, showed higher efficiency. The average level of technical efficiency of the chosen half-normal model was estimated at $48.6 \%$, ranging from a minimum of $2.0 \%$ to a maximum of $95.3 \%$. Compared with other farms in the Mediterranean region, the relatively low efficiency scores suggest the existence of substantive farm level inefficiencies. Comparing average efficiency scores between irrigated and non-irrigated farms, we found the effect of irrigation to be marginal. Overall, our results suggest that olive farms in Jenin have the potential to increase their production by $51.4 \%$ through more efficient use of technology and production inputs.

These results imply that the promotion of intensive farms with mature olive trees and expanding access to markets would contribute to upgrade the efficiency of olive farms in the West Bank operating under severe geographical and geopolitical constraints. As Beaufoy (2001) suggested, intensification of olive farming with irrigation is becoming increasingly widespread in many regions of Mediterranean countries. The results of this study provide the empirical evidence to support the adoption of more intensive farming by means of irrigation, highly densified plantation (increase in tree density) with continuous irrigation (increase in years of irrigation). Our study also implies the promotion of intensive farming with irrigation rather than a mere expansion of irrigated area would be effective to realize the best practice for olive production even under the severe condition of water scarcity.

\section{Acknowledgments}

The author gratefully acknowledged that this research was supported by the Japan Science for Promotion of Sciences (JSPS) under the Grant-in-Aid for Challenging Exploratory Research, No. 26590035, entitled: "Research on Promotion and Development of Olive Industries in West Bank for Peace and Prosperity". The author thanks the Palestinian Central Bureau of Statistics for their collaboration in implementing the survey of Jenin.

\section{References}

Abugamea, G. H. (2010). The competitiveness of the Palestinian foreign trade: A cointegration analysis. ERF 
Working Paper Series, No.541. Cairo: Economic Research Forum.

Aigner, D. J., Lovell, C. A. K., \& Schmidt, P. (1977). Formulation and estimation of stochastic frontier production function models. Journal of Econometrics, 6, 21-37. https://doi.org/10.1016/0304-4076(77)90052-5

Ali, F., Parikh, A., \& Shah, M. (1994). Measurement of profit efficiency using behavioral and stochastic frontier approaches. Applied Economics, 26, 181-188. https://doi.org/10.1080/00036849400000074

Amores, A. F., \& Contreras, I. (2009). New approach for the assignment of new European agricultural subsidies using scores from data envelopment analysis: Application to olive-growing farms in Andalusia (Spain). European Journal of Operational Research, 193(3), 718-729. https://doi.org/10.1016/j.ejor.2007.06.059

Artukoglu, M. M., Olgun, A., \& Adanacioglu, H. (2010). The efficiency analysis of organic and conventional olive farms: Case of Turkey. Agric. Econ-Czech, 56(2), 89-96.

Astrup, C., \& Dessus, S. (2001). Exporting labor or goods? Long-term implications for the Palestinian economy. ERF Working Paper Series, No.0131. Cairo: Economic Research Forum.

Battese, G. E., \& Coelli, T. J. (1995). A model for technical inefficiency effects in a stochastic frontier production function for panel data. Empirical Economics, 20, 325-332. https://doi.org/10.1007/BF01205442

Bozoğlu, M., \& Ceyhan, V. (2007). Measuring the technical efficiency and exploring the inefficiency determinants of vegetable farms in Samsun province, Turkey. Agricultural Systems, 94, 649-656. https://doi.org/10.1016/j.agsy.2007.01.007

Bravo-Ureta, B., \& Evenson, R. E. (1994). Efficiency in agricultural production: The case of peasant farmers in eastern Paraguay. Agricultural Economics, 10, 27-37. https://doi.org/10.1016/0169-5150(94)90037-X

Bravo-Ureta, B., Solís, D., Moreira, V., Maripani, J., Thiam, A., \& Rivas, T. (2007). Technical efficiency in farming: A meta-regression analysis. Journal of Productivity Analysis, 27(1), 57-72. https://doi.org/10.1007/s11123-006-0025-3

Beaufoy, G. (2001). The environmental impact of olive oil production in the European Union: Practical options for improving environmental impact. European Forum on Nature Conservation and Pastoralism and the Asociación para el Análisis y Reforma de la Política Agro-rural.

Chebil, A., Frija, A., \& Thabet, C. (2015). Economic efficiency measures and its determinants for irrigated wheat farms in Tunisia: A DEA approach. New Medit, 2, 32-38.

Coelli, T. J., Rao, D. S. P., O’Donnell, C. J., \& Battese, G. E. (2005). An introduction to efficiency and productivity analysis (2nd ed.). New York: Springer.

Cukur, F., Saner, G., Cukur, T., Dayan, V., \& Adanacioglu, H. (2013). Efficiency analysis of olive farms: The case study of Mugla province, Turkey. Journal of Food, Agriculture and Environment, 11(2), 317-321.

Davidson, R., \& MacKinnon, J. (1993). Estimation and inference in econometrics. New York and Oxford: Oxford University Press.

Farrell, M. J. (1957). The measurement of productive efficiency. Journal of the Royal Statistical Society, Series $A$ (120), 253-290. https://doi.org/10.2307/2343100

Frija, A., Chebil, A., Speelman, S., Buysse, J., \& Van Huylenbroeck, G. (2009). Water use and technical efficiencies in horticultural greenhouses in Tunisia. Agriculture Water Management, 96, 1509-1516. https://doi.org/10.1016/j.agwat.2009.05.006

Gorton, M., \& Davidova, S. (2004). Farm productivity and efficiency in the CEE applicant countries: A synthesis of results. Agricultural Economics, 30, 1-16. https://doi.org/10.1016/j.agecon.2002.09.002

Greene, W. H. (1990). A gamma-distributed stochastic frontier model. Journal of Econometrics, 46(1-2), 141-163. https://doi.org/10.1016/0304-4076(90)90052-U

Hallam, D., \& Machado, F. (1996). Efficiency analysis with panel data: A study of Portuguese dairy farms. European Review of Agricultural Economics, 23, 79-93. https://doi.org/10.1093/erae/23.1.79

Hart, J., Miljkovic, D., \& Shafik, S. (2015). The impact of trade openness on technical efficiency in the agricultural sector of the European Union. Applied Economics, 47(12), 1230-1247. https://doi.org/10.1080/00036846.2014.993134

Hassine, N. B. (2007). Technical efficiency in the Mediterranean countries' agricultural sector. Région et 
Développement, 25, 27-44.

Huang C. J., \& Liu, J. T. (1994). Estimation of a non-neutral stochastic frontier production function. Journal of Productivity Analysis, 2, 171-180. https://doi.org/10.1007/BF01073853

Jondrow, J., Lovell, C. A. K., Materov, I. S., \& Schmidt, P. (1982). On the estimation of technical inefficiency in stochastic frontier production function model. Journal of Econometrics, 19, 233-238. https://doi.org/10.1016/0304-4076(82)90004-5

Kalirajan, K., \& Shand, R. (1985). Types of education and agricultural productivity: A quantitative analysis of Tamil Nadu rice farming. Journal of Development Studies, 21, 222-243. https://doi.org/10.1080/00220388508421940

Karagiannis, G., \& Tzouvelekas, V. (2001). Self-dual stochastic production frontiers and decomposition of output growth: The case of olive-growing farms in Greece. Agricultural and Resource Economics Review, 30(2), 168-178. https://doi.org/10.1017/S1068280500001118

Kumbhakar, S. C., Ghosh, S., \& McGuckin, J.T. (1991). A generalized production frontier approach for estimating determinants of inefficiency in U.S. dairy farms. Journal of Business and Economic Statistics, 9, 279-286. https://doi.org/10.1080/07350015.1991.10509853

Lachaal, L., Dhehibi, B., Chebil, A., \& Karray, B. (2004). Technical efficiency measures and its determinants for olive producing farms in Tunisia. In Emrouznejad, A., \& Podinovski, V. (Eds.), Data envelopment analysis and performance management (pp. 317-323). Coventry: Warwick Print.

Lachaal, L., Karray, B., Dhehibi, B., \& Chebil. A. (2005). Technical efficiency measures and its determinants for olive producing farms in Tunisia: A stochastic frontier analysis. African Development Review, 17(3), 580-591. https://doi.org/10.1111/j.1017-6772.2006.00129.x

Lambarraa, F., Serra, T., \& Gil, J. M. (2007). Technical efficiency analysis and decomposition of prductivity gowth of Spanish oive farms. Spanish Journal of Agricultural Research, 5(3), 259-270. https://doi.org/10.5424/sjar/2007053-247

Meeusen, W., \& van den Broeck, J. (1977). Efficiency estimation from Cobb-Douglas production function with composed error. International Economic Review, 18, 435-444. https://doi.org/10.2307/2525757

Miljkovic, D., \& Shaik, S. (2010). The impact of trade openness on technical efficiency in U.S. agriculture. Agribusiness \& Applied Economics Report No. 660. Department of Agribusiness and Applied Economics, North Dakota State University.

Miljkovic, D., Miranda, S. H., \& Shaik, S. (2013). Trade openness and technical efficiency in Brazilian agriculture. Applied Economics Letters, 20, 103-106. https://doi.org/10.1080/13504851.2012.684870

Ministry of Agriculture, State of Palestine (2014). The national strategy for olive and olive oil sector in Palestine (2014-2019). Ramallah: Ministry of Agriculture, State of Palestine, September.

Naquib, F. M. (2013). Economic aspects of the Palestinian-Israel conflict: The collapse of the Oslo accord. Journal of International Development, 15, 499-512. https://doi.org/10.1002/jid.999

Ozden, A., \& Dios-Palmores, R. (2016). Is the olive oil an efficient sector? A meta frontier analysis considering the ownership structure. New Medit, 15(3), 2-9.

Palestinian Central Bureau of Statistics (PCBS) (2012). Agricultural statistics survey 2010/2011. Ramallah-Palestine.

Palestinian Central Bureau of Statistics (PCBS) (2015a). Registered foreign trade statistics - goods and services, 2014: Main results. Ramallah-Palestine.

Palestinian Central Bureau of Statistics (PCBS) (2015b). Olive presses survey. Ramallah-Palestine.

Proietti, P., \& Antognozzi, E. (1996). Effect of irrigation on fruit quality of table olives (Olea Europaea), cultivar 'Ascolana Tenera'. New Zealand Journal of Crop and Horticultural Science, 24(2), $175-181$. https://doi.org/10.1080/01140671.1996.9513950

Reifschneider, D., \& R. Stevenson. (1991). Systematic departures from the frontier: A framework for the analysis of firm inefficiency. International Economic Review, 32, 715-723. https://doi.org/10.2307/2527115

Roy, S. (1999). De-development revisited: Palestinian economy and society since Oslo. Journal of Palestine Studies, 28(3), 64-82. https://doi.org/10.2307/2538308 
Saldias, R., \& von Cramon-Taubadel, S. (2012). Access to credit and the determinants of technical inefficiency among specialized small farmers in Chile. Diskussionspapiere. Department für Agrarökonomie und Rurale Entwicklung 1211, Universität Göttingen.

Solís D., Bravo-Ureta, B. E., \& Quiroga, R. E. (2009). Technical efficiency among peasant farmers participating in natural resource management programmes in Central America. Journal of Agricultural Economics, 60(1), 202-219. https://doi.org/10.1111/j.1477-9552.2008.00173.x

Speelman, S., D’Haese, M., Buysse, J., \& D'Haese, L. (2008). A measure for the efficiency of water use and its determinants: A case study of small-scale irrigation schemes in north-west province, South Africa. Agricultural Systems, 98, 235-243. https://doi.org/10.1016/j.agsy.2008.03.006

Stefanou, S., \& Saxena, S. (1988). Education, experience and allocative efficiency: A dual approach. American Journal of Agricultural Economics, 2, 338-345. https://doi.org/10.2307/1242074

Stevenson, R. E. (1980). Likelihood functions for generalized stochastic frontier estimation. Journal of Econometrics, 13(1), 57-66. https://doi.org/10.1016/0304-4076(80)90042-1

Tzouvelekas, V., Giannakas, K., Midmore, P., \& Mattas, K. (1997). Technical efficiency measures for olive-growing farms in Crete, Greece. International Advances in Economic Research, 3(2), 154-169. https://doi.org/10.1007/BF02294936

Tzouvelekas, V., Giannakas, K., Midmore, P., \& Mattas, K. (1999). Decomposition of olive oil production growth into productivity and size effects: A frontier production function approach. Cahiers d'économie et Sociologie Rurales, 51, 5-21.

Tzouvelekas V., Pantzios, C. J., \& Fotopoulos, C. (2001). Technical efficiency of alternative farming systems: The case of Greek organic and conventional olive-growing Farms. Food Policy, 26, 549-569. https://doi.org/10.1016/S0306-9192(01)00007-0

UNCTAD (2011). Rebuilding the Palestinian tradable goods sector: Towards economic recovery and state formation. New York and Geneva: United Nations.

UNCTAD (2015). The besieged Palestinian sector. New York and Geneva: United Nations.

Valipour, M. (2012a). Hydro-module determination for Vanaei village in Eslam Abad Ghrab, Iran. ARPN Journal of Agricultural and Biological Science, 7(12), 968-976.

Valipour, M. (2012b). A Comparison between horizontal and vertical drainage systems (include pipe drainage, open ditch drainage, and pumped wells) in anisotropic soils. IOSR Journal of Mechanical and Civil Engineering, 4(1), 7-12. https://doi.org/10.9790/1684-0410712

Valipour, M. (2013a). Increasing irrigation efficiency by management strategies: Cutback and surge irrigation. ARPN Journal of Agricultural and Biological Science, 8(1), 35-43.

Valipour, M. (2013b). Necessity of irrigated and rainfed agriculture in the world. Irrigation \& Drainage Systems Engineering, S9, e001. https://doi.org/10.4172/2168-9768.S9-e001

Valipour, M. (2013c). Evolution of irrigation-equipped areas as share of cultivated areas. Irrigation \& Drainage Systems Engineering, 2(1), e114. http://dx.doi.org/10.4172/2168- 9768.1000e114

Valipour, M. (2013d). Use of surface water supply index to assessing of water resources management in Colorado and Oregon, US. Advances in Agriculture, Sciences and Engineering Research, 3(2), 631-640.

Valipour, M. (2015a). Future of agricultural water management in Africa. Archives of Agronomy and Soil Science, 61(7), 907-927. https://doi.org/10.1080/03650340.2014.961433

Valipour M. (2015b). Land use policy and agricultural water management of the previous half of century in Africa. Applied Water Science, 5(4), 367-395. https://doi.org/10.1007/s13201-014-0199-1

Valipour, M. (2016a). How much meteorological information is necessary to achieve reliable accuracy for rainfall estimations? Agriculture, 6(4), 53. https://doi.org/10.3390/agriculture6040053

Valipour, M. (2016b). How do different factors impact agricultural water management? Open Agriculture, 1(1), 89-111. https://doi.org/10.1515/opag-2016-0014

Weissteiner, C. J., Strobl, P., \& Sommer, S. (2011). Assessment of status and trends of olive farming intensity in EU-Mediterranean countries using remote sensing time series and land cover data. Ecological Indicators, 11(2), 601-610. https://doi.org/10.1016/j.ecolind.2010.08.006 
Wooldridge, J. M. (2002). Econometric analysis of cross section and panel data. Cambridge, Massachusetts, London: MIT Press.

World Bank (2006). Brief overview of the olive and the olive oil sector in the Palestinian territories. World Bank. Retrieved September 27, 2016, from https://unispal.un.org/pdfs/WB_olive_2006.pdf

\section{Notes}

Note 1. Dunum is a term used in Palestine to describe an area of land of 1,000 square meters (one tenth of hectare. See Ministry of Agriculture, State of Palestine (2014).

Note 2. Bravo-Ureta, Solís, Moreira, Maripani, Thiam and Rivas (2007) offer a comprehensive review of studies on technical efficiency in farming from methodological viewpoints. The study targeting olives was just one of the 167 studies.

Note 3. Amores and Contreras (2009) categorized the intensity of olive farming in Andalusia by differentiating olive farms with more than and less than 140 trees per ha.

\section{Copyrights}

Copyright for this article is retained by the author(s), with first publication rights granted to the journal.

This is an open-access article distributed under the terms and conditions of the Creative Commons Attribution license (http://creativecommons.org/licenses/by/3.0/). 